Full-text Available Online at www.ajol.info and www.bioline.org.br/ja

\title{
Comparative Analysis of Profitability of Layers Production in Esan North East and Ovia North East Local Government Areas of Edo State, Nigeria
}

\author{
*11EMOKARO CO; PO; ERHABOR
}

\author{
Department of Agricultural Economics and Extension Services, Faculty of Agriculture, \\ University of Benin, P.M.B. 1154, Benin City, Edo State, Nigeria.
}

KEY WORDS: Day old Chicks, Gross Margin, old layers, Point of lay, Profitability, Rate of return, Viability.

\begin{abstract}
This study examined profitability in layers production from day old chicks to point of lay in Esan North East and Ovia North East Areas of Edo State. A simple random sampling of 135 poultry farmers was carried out in the study area in order to generate data for the analysis. Data collected were analyzed using Net Profit (NP), Gross Margin (GM), Benefit Cost Ratio (BCR), Rate of Return on Investment (RRI), Rate of Return on Fixed Cost (RRFC), Rate of Return on Variable Cost (RRVC) and Return per Naira invested (R/N) and . Results of the study showed that the business of layers production was profitable and viable in the study area with the following mean indices; $B C R=\$ 1.39, \quad \mathrm{RRI}=\$ 138.67$, $\mathrm{RRFC}=\$ 2,097.12$ RRVC $\$ 139.43$ and $\mathrm{R} / \mathrm{N}=\$ 0.41$ in. the mean gross revenue for the respondents was computed as $\$ 7,324,350$, with a gross margin of $\$ 2,144,638.00$ and net profit was $\$ 2,042,371.96$. Result of the regression analysis showed that three of the eight explanatory variables contributed significantly to income earned from poultry business; these are fixed cost $(\mathrm{P}<0.10)$, layers mash $(\mathrm{P}<0.01)$ and miscellaneous expenses $(\mathrm{P}<0.05)$.

(C) JASEM
\end{abstract}

\section{http://dx.doi.org/10.4314/jasem.v18i1.17}

The problem of malnutrition has remained an unresolved global issue for a long time. FAO (1995), asserted that the most critical in the global food basket crises is protein, especially of animal origin. However, Oluyemi and Roberts (2000) and Isika et al., (2006), postulated that poultry was strategic in addressing animal protein shortage in human nutrition.

Development of the poultry industry is a viable option in bridging the perennial protein deficiency gap in a Nigerian's diet. Apart from this, the industry contributes immensely to the Gross Domestic Product and provides employment opportunities to several categories of people in Nigeria.

Poultry production is predominant among livestock production in Edo State. People depend on poultry for food and poultry farming serves as an additional occupation to supplement the income of small and marginal farm families. Poultry occupies an essential position because of its vast potential to bring about rapid economic growth, particularly benefiting the weaker section of the economy (Ekunwe et al., 2006).

\section{*Corresponding author Email: emokaro@yahoo.com}

For Nigeria to attain rapid economic growth and development, there is the need for attention to be paid to all sectors of agriculture. There is the need for significant improvements in the livestock industry and poultry in particular. Events of the past decades indicate that the demand and supply gap for animal protein intake is so high (Yusuf and Malomo, 2007). Poultry farmers, like other producers in the agricultural sector are rational, thus, they would increase their supply if they are sure of making higher profit ceteris paribus (Emokaro et al., 2009). Higher profit thus ensures the sustainability of the industry. Again, poultry business, like any other farming endeavour, is fraught with a lot of risks and uncertainties. To circumvent these, poultry farmers try out several production methods in a bid to irk out reasonable earnings. Some go the whole hog by raising their birds from day old chicks to spent layers, while others prefer to buy mature birds that are at the "point of lay" and concentrate only on table eggs production, eventually selling off the spent birds as "old layers". The third category simply raise their birds from day old chicks to "point of lay" and sell them off to the second category. The research questions that arise from this is whether such poultry farmers are making enough profit from their 
respective production effort? Is the decision of which of these three production options to take influenced by their relative profitability? It is also important to ask whether the farmers face any production constraints that could impinge on the sustainability of the industry?

The research interest here was thus to compare the profits realizable from these three prevalent production options in the study area, and suggest how the industry can be sustained, based on the estimated profitability indices. The objective of the study was thus to investigate the profitability of layers' production and compare profit realizable from the three common production options in the study area, i.e.; (i) day old chicks to spent layers (ii) point of lay to spent layers (iii) day old chicks to point of lay. Although much work have been done in the area of profitability analyses, this particular approach is still novel. This study is an attempt at filling this gap.

\section{METHODOLOGY}

This study was carried out in Ovia North East and Esan North East Local Government Areas (L.G.A.s) of Edo State. Ovia North East Local Government occupies a land area of $2,351.255 \mathrm{~km}^{2}$, and consists of thirteen (13) political wards with its headquarters located at Okada. This L.G.A. cuts through Longitudes $5.5^{\circ} \mathrm{E}-5.6^{\circ} \mathrm{E}$ in the Southern part and this gives the area a "Y" shape. The population of the LGA is 155,849 persons of which, 81,690 are males and 72,759 are females (NPC, 2006). The area is lowland and rises up to about 100 meters above sea level. It falls within the rain forest zone with tall trees and oil palm trees, and in the extreme Southern area, most parts are covered by the mangrove and fresh swamp forest. On the other hand, Esan North East L.G.A. has an estimated population of 119,346. It is bordered by Atani (Ubiaja), Ebhoiyi (Igueben) Ivue obeidu (Irrua) Uzea (Afemai), Amendokhian (Ugboha), with towns in all its surroundings (NPC, 2006).

The sampling technique adopted in this study involved a two staged sampling process which combined purposive and random sampling methods. In the first stage, farmers who had a flock size of not less than 650 (layers) birds were purposively selected within Ovia North East and Esan North East Local Government Areas of Edo State.

In the second stage, a random sampling method was used to select 75 and 60 respondents respectively from Ovia North East and Esan North East L.G.A.s, based on the higher number of poultry farmers found in the former. This was done in the absence of a comprehensive list of all the poultry farmers within the study area. A total of 135 poultry farmers were thus selected.

Primary data sourced with the use of well structured questionnaire were used in this study. The questions were designed to elicit information on six (6) different variables, the revenue accruable to poultry farmers from egg and layers production, accrued cost from egg production, accrued cost from day old chicks to point of lay production and the constraints faced by poultry farmers in the study area.

The data obtained from the questionnaire were analyzed using budgetary analysis techniques, as defined below:

(i) $\quad$ Gross Margin $(\mathrm{GM})=$ Total Revenue (TR) - Total Variable Cost (TVC)

(ii) Rate of Return on Investment (RRI) $=\underline{\text { Revenue }} \times 100$ Total Cost

(iii) Rate of Return on fixed cost $(\mathrm{RRFC})=$ Total Revenue - Total Variable Cost x 100 Total fixed cost

(iv) Rate of Return on Variable Cost (RRVC) $=$ Total Revenue - Total Fixed cost x 100

Total variable cost

(v)

TVC

The depreciation of fixed cost was calculated using the straight line method of depreciation.

$\mathrm{D}=\frac{\mathrm{C}-\mathrm{S}}{\mathrm{N}}$

Where

$\mathrm{D}=$ Depreciated amount

$\mathrm{C}=$ Initial cost of the assets

$\mathrm{S}=$ Salvage value

$\mathrm{N}=$ Expected number of useful life span

The salvage value was assumed to be zero. Layers production was appraised using the Benefit Cost Ratio (BCR).

$\mathrm{BCR}=$ Discounted total Farm Benefit

Discounted total cost incurred

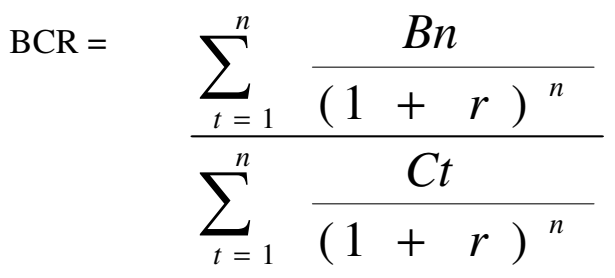


Where: $\mathrm{Bn}=$ Benefit in each year; $\mathrm{Ct}=\mathrm{Cost}$ in each farming year; $n=$ Number

The ordinary least square technique was used to determine the relationship existing between the naira value of and the input used by the respondents for the entire production circle of day old chicks to spent layers (Adesina and Kehinde, 2008 and Ayinde et al., 2011). The implicit form of the function is: $Y=f$ $\left(\mathrm{X}_{1}, \mathrm{X}_{2}, \mathrm{X}_{3}, \mathrm{X}_{4}, \mathrm{X}_{5}, \mathrm{X}_{6}, \mathrm{X}_{7}, \mathrm{X}_{8} \mathrm{e}\right)$. While the explicit form is:

$Y=b_{0}+b_{1} X_{1}+b_{2} X_{2}+b_{3} X_{3}+b_{4} X_{4}+b_{5} X_{5}+b_{5} X_{5}+b_{6} X_{6}$ $+b_{7} X_{7}+b_{8} X_{8}+e$

Where: $Y=$ Total revenue (Naira), $\mathrm{X}_{1}=$ Labour (Naira), $X_{2}=$ starters mash (Naira)

$\mathrm{X}_{3}=$ growers mash (Naira), $\mathrm{X}_{4}=$ layers mash (Naira), $X_{5}=$ Medication (Naira), $X_{6}=$ Electricity consumption (in $\mathrm{Kw} / \mathrm{h}$ ), $\mathrm{X}_{7}=$ Miscellaneous (charcoal, disinfectant, kerosene, transportation, wood shavings) (Naira), $\mathrm{X}_{8}=$ Fixed cost (battery cages, boreholes, drinkers, feeders, poultry buildings, wheel barrows, etc.) (Naira), e = the error term.

\section{RESULTS AND DISCUSSION}

Results presented and discussed in this section is in the three identified production options of (i) day old chicks to spent layers (ii) point of lay to spent layers (iii) day old chicks to point of lay. The cost of production is usually categorized into fixed and variable cost. The fixed cost of the farmer, are cost which cannot be used up during the course of production. In this study, such costs were poultry houses, feeding troughs and drinkers, cages, wheelbarrows, spades and other farm implements. Items that constituted the variable cost included day old chicks, feeds, cost of medication, labour and electricity (utility).

As presented in Table 1, the average farmer in this option incurred a total cost of $\$ 10,121,736.14$ out of which $\$ 9,932,767.80$ was total variable cost and $\$ 188,968.34$ was average depreciated fixed cost for the production season. The Gross revenue realized from the sales of egg, culled layers and spent layers was computed to be $\$ 16,575,106.4$ on the average, in $2009 / 2010$ production season. The gross margin that accrued from 1,676 layers was therefore $\$ 6,642,338.6$, while net profit was $\$ 6,453,370.26$. the return / Naira invested of 0.67 indicates a $67 \%$ return on investment

Results indicate that, at the close of the operation, the average poultry farmer in the study area incurred a total cost of $\$ 10,732,069.98$ in raising his birds from point of lay to spent layers (Table 2). Out of this, $10,567,206.67$ was total variable cost and $\$ 164,863.31$ was average depreciated fixed cost for the production season. The gross revenue from the sales of egg, culled layers and spent layers was computed as $\$ 16,575,106.4$ in $2009 / 2010$ production season. The Gross margin realized was $\$ 6,007,899.73$, with a net profit of $\$ 5,843,036.42$ and $57 \%$ return on investment.

Table 1: Mean Cost and Returns for the Production of 1,676 birds in the 2009/2010 Farming Season in the Study Area

\begin{tabular}{lccc}
\hline Item & DOC - SL & PL - SL & \multicolumn{2}{c}{ DOC - SL } \\
Total fixed cost (N) & $188,968.34$ & $164,863.31$ & $102,266.04$ \\
Total variable cost (N) & $9,932,327.80$ & $10,567,206.67$ & $5,179,712.00$ \\
Total revenue (N) & $16,575,106.40$ & $16,575,106.40$ & $7,324,350.00$ \\
Gross margin (N) & $6,642,338.60$ & $6,007,899.73$ & $2,144,638.00$ \\
Net profit (N) & $6,453,370.26$ & $5,843,036.42$ & $2,042,371.96$ \\
Return/Naira (N) & 0.67 & 0.57 & 0.41 \\
BCR & 1.64 & 1.54 & 1.39 \\
RRI & 163.76 & 163.76 & 138.67 \\
RRFC & 3515.29 & 3515.05 & 2097.12 \\
RRVC & 164.98 & 164.97 & 139.43 \\
\hline
\end{tabular}

Source: Field Data, 2011

*DOC - SL: from day old chicks to spent layers; **PL - SL: from Point of Lay to Spent Layers; $* * *$ DOC - SL: from day old chicks to point of lay.

At the end of the production year, the poultry farmer that concentrated on the production of layers to the "point of lay", on the average, expended a total estimated variable cost of $\$ 5,179,712.00$ and a total depreciated fixed cost of $\$ 102,266.04$ in the 2009/2010 farming season. This leaves us with a total cost of $\$ 5,281,978.04$, with the implication that $98 \%$ of the production cost was accounted for by variable inputs. The mean Gross revenue that accrued from the sales of the mature birds (at point of lay) was estimated as $\$ 7,324,350$ in the $2009 / 2010$ farming season. The annual gross margin realized from the 
production of 6,704 pullets was therefore $\$ 2,144,638.00$, giving us a profit of approximately N400/ bird and a return on investment of $41 \%$.

The results so far presented shows the different profit levels from the (i) day old chicks to spent layers, point of lay to spent layers and Day old chicks to point of lay, using different indices. It was observed that the Return per Naira Invested was highest in production option of raising birds from day old chicks to spent layers (0.67) and lowest in the third option of raising birds from day old chicks to pointof-lay (0.41). The most probable economic explanation for this is the obvious benefit of vertical integration, which was maximized by the first production option of going the whole hog of raising birds right from day old chicks to spent layers. The respective enterprises were however, shown to be viable in the study area, going by the values of the BCR (all > 1). For the purpose of higher returns and sustainability, poultry farmers in the study area may wish to concentrate on raising their own birds, right from bay old chicks.

These results agrees with the findings of Emokaro, et al. (2009), who reported that variable inputs accounted for most of the cost incurred in farming, although Ekunwe and Sorenigun (2007), in a separate study on poultry egg production, reported a slightly lower value of about $60 \%$ total variable cost. The results on profitability, compares favourably with the results of Eduvi (2002), who reported on costs and returns in alternative poultry production management systems, where intensive management was shown to be more profitable than semi intensive management as indicated by the BCR of 2.2 to 1.0 and 2.0 to 1.0 for the two systems respectively.

Results of the multiple regression for poultry production for the complete circle of day old chicks to spent layers is presented in Table 2. Two functional models were used, with the linear model preferred to the double log model on the basis of its higher $R^{2}$, adjusted $R^{2}$ and $F$-values; the reasonableness of the magnitude of the respective coefficients and $a$ priori econometric expectations of signs of the estimated parameters (Koutsoyannis, 2003; Gujarati, 2004; Emokaro and Erhabor, 2006; Emokaro and Ekunwe, 2007). The results showed that the F- value was significant $(\mathrm{P}<0.01)$. This implies that the model used was appropriate. The adjusted $\mathrm{R}^{2}$ of 0.89 implies that $89 \%$ of the variation in respondents' revenue can be explained by the model.

Only three of the eight explanatory variables were found to be significant, these are fixed cost $(\mathrm{P}<$ $0.10)$, layers mash $(\mathrm{P}<0.01)$ and miscellaneous $(\mathrm{P}<$ $0.05)$. Miscellaneous expenses and layers' mash had positive impact on revenue, which means that increase in layers' mash and miscellaneous expenses would lead to increase in revenue for the respondent. Fixed cost was observed to have negative effect on revenue; this means that the bigger the amount of money tied up in fixed capital (which could actually have been sourced from sources of credit), the smaller the working capital, this is in agreement with the report of Omotosho (1997).

Table 2: Multiple Regression Models estimated from Day Old Chicks to Spent Layers.

\begin{tabular}{|c|c|c|c|c|c|c|}
\hline \multirow[b]{2}{*}{ Variable } & \multicolumn{3}{|c|}{ Double Log Model } & \multicolumn{3}{|c|}{ Linear Model } \\
\hline & Coefficient & Std. error & $\mathrm{t}$-stat & Coefficient & Std. error & t-stat \\
\hline $\begin{array}{l}\text { Labour }\left(X_{1}\right) \\
\text { starters mash }\left(X_{2}\right)\end{array}$ & 0.4429 & 0.2251 & 1.9672 & 4.9817 & 3.9649 & 1.2565 \\
\hline & 0.0892 & 0.0850 & 1.0489 & -0.0402 & 0.0737 & -0.5462 \\
\hline $\begin{array}{l}\text { growers mash }\left(X_{3}\right) \\
\text { layers mash }\left(X_{4}\right)\end{array}$ & 0.0612 & 0.1415 & 0.4322 & 0.0036 & 0.0086 & 0.4216 \\
\hline Medication $\left(\mathrm{X}_{5}\right)$ & 0.6216 & 0.1442 & 4.3104 & 9.0089 & 0.6087 & $* * * 14.8013$ \\
\hline Electricity & -0.0162 & 0.0983 & -0.1642 & -0.0053 & 0.0037 & -1.4546 \\
\hline $\begin{array}{l}\text { consumption }\left(\mathrm{X}_{6}\right) \\
\text { Miscellaneous }\left(\mathrm{X}_{7}\right)\end{array}$ & 0.2720 & 0.1952 & 1.3935 & 0.0073 & 0.0791 & 0.0930 \\
\hline Fixed cost $\left(\mathrm{X}_{8}\right)$ & -0.0501 & 0.1464 & -0.3424 & 0.0136 & 0.0066 & $* * 2.0547$ \\
\hline Constant & -0.1937 & 0.2239 & -0.8649 & -0.0002 & $9.89 \mathrm{E}-05$ & $*_{-1.7150}$ \\
\hline & $\begin{array}{l}\quad 2.5853 \\
\text { R-squared } \\
\text { Adjusted R-squared } \\
\text { F-statistic }\end{array}$ & 2.1928 & $\begin{array}{r}1.1790 \\
0.81 \\
0.79 \\
24.96\end{array}$ & $\begin{array}{l}\quad-34.0721 \\
\text { R-squared } \\
\text { Adjusted R-squared } \\
\text { F-statistic }\end{array}$ & 144.4299 & $\begin{array}{r}-0.2359 \\
0.92 \\
0.89 \\
377.22\end{array}$ \\
\hline
\end{tabular}

Source: Field survey Data, 2011. *** $(P<0.01)$, ** $(P<0.05), *(P<0.01)$. 
The most important constraints faced by the respondents were tabulated for each farmer and the highest picked per farmer, as presented in the Table 3. Results indicate that $36 \%$ of the respondents ranked the problem of disease as the most serious constraint they faced in the production process. This could be as a result of poor veterinary services or poor adoption of innovations on the part of the poultry farmers. Inadequate finance, which is an important factor in production, ranked second among the constraints encountered by poultry farmers in the study area. Poaching constituted $20 \%$ of the constraints encountered in poultry farming in the study area. This could be as a result of insincerity among employees in poultry farms. The problem of disposing droppings and problem of personnel ranked last in the table of constraints, this implies they do not constitute major problems to the poultry farmers. The possible solution to the problems could come through government intervention in the areas of drug and veterinary services so as to minimize the effect of disease and mortality of birds. Financial constraints reported by respondents could be indirectly responsible for high poaching $(20 \%)$, probably due to inadequate funds to put the necessary security network in place. A high level of automation can reduce poaching drastically, and this will require high capital investment on the part of investors. Government should therefore provide funds at low interest rates for the farmers. This would have a positive multiplier effect on the general economy and health of Nigerians.

Table 4: Constraints Encountered by Farmers engaged in Poultry Farm

\begin{tabular}{llc}
\hline Problems & Frequency & Percentage \\
\hline Disease & 48 & 35.60 \\
Inadequate finance & 36 & 26.70 \\
Poor quality personnel & 12 & 8.90 \\
Disposing of droppings & 12 & 8.90 \\
Poaching & 27 & 20.00 \\
Total & $\mathbf{1 3 5}$ & $\mathbf{1 0 0 . 0 0}$ \\
\hline
\end{tabular}

Source: Field survey Data, 2011

Based on the findings the following recommendations are hereby given to improve poultry farming in the study area; (i) Poultry farmers in the study area are advised to concentrate on raising their own birds, right from day old chicks, this would ensure higher returns and sustainability. (ii) Improved veterinary services that are targeted at reducing incidence of disease in layer flock so as to reduce the cost of medication and lower the mortality rate. (iii) More youth should be advised to go into layers production since it has been proven to be profitable in the study areas. This will provide job opportunities for the teeming population that are unemployed as well as provide or bridge the gap of protein shortage in the Country Nigeria. (iv) Government should mandate commercial banks to reserve a certain percentage of the budget for the poultry farmers at low interest rate. A type of selective policy that will make funds to be available to the targeted sub-sector of the economy should be adopted.

\section{REFERENCES}

Adesina, C A; Kehinde, A L (2008). Economics of Wholesales Marketing of Tomato

Fruits in Ibadan Metropolis of Oyo State, Nigeria. In: Umeh, J.C.; C.P. Obinne and W. Lawal (eds.). Proceedings of $22^{\text {nd }}$ Annual National Conference of Farm Management Association of Nigeria (FAMAN), Makurdi, $08^{\text {th }}-11^{\text {th }}$, September, 2008, pp 51-59.

Ayinde, I A; Ibrahim S B; Arowolo, S O (2011). Economics of Poultry Egg Production

Under Different Management Systems in Odeda Local Government Area, Ogun State. In: Erhabor, P. O.; C.I. Ada-Okungbowa; C.O. Emokaro and M.O. Abiola (eds.) National Association of Agricultural Economists (NAAE), $12^{\text {th }}$ Annual National Conference Proceedings, University of Benin, $12^{\text {th }}-16^{\text {th }}$ of Nov., 2011. Pp. 546-554.

Eduvi, L O (2002). Poultry Production as an important component of Nigeria Livestock subsector. A training manual on National Training Workshop on Poultry Production in Nigeria in Napri, ABU, Shika, Zaria, Nigeria

Ekunwe, P A; Soniregun O O; Oyedeji, J O (2006). Economics of Small Scale Deep Litter System of Egg Production in Oredo Local Government Area of Edo State Nigeria. Int. J. Poult. Sci. 5(1): $81-83$.

Ekunwe, P A; Soniregun, O O (2007). Profitability and Constraints of Median Scale Battery Cage System of Poultry Egg Production in Edo State, Nigeria. Int. J. Poult. Sci. 6(2): 118-121.

Emokaro, C O; Ekunwe, P A; Achille, A (2009). Profitability and viability of catfish farming in Kogi State, Nig. Res. J Agric, \& Bio Sc. 5 (7): 776-779. 
Emokaro, C O; Ekunwe, P A (2007). Efficiency of Resource-Use and Marginal productivities in Dry Season Amaranth Production in Edo South, Nigeria. J App. Sc. 7 (17): 2500-2504.

Emokaro, C O; Erhabor, P O (2006). "Efficiency of Resource-use in Cassava Production in Edo State, Nigeria". Journal of Agriculture Forestry and the Social Sciences. 4(1): 22-29.

Etuk, E A; Agom, D I; Isika, M A; Idiong, I C (2007). Resource Use Efficiency Broiler Enterprises in Cross River State, South Eastern Nigeria. Int. J. Poult. Sci. 6(1): 23-26

FAO (1995). Food and Agricultural Organization of United Nations. The State of Food and Agric., Rome, Italy.

Gujarati, D N (2004). Basic Econometris.

Isika, M A; Agiang E A; Okon, B I (2006). Dietary Energy and Crude Protein Requirements for Chicks of Nigeria Local Fowl and Crossbreeds. Int. J. Poult. Sci., 5:.271-274.
Koutsoyiannis, A (2001). Theory of Econometrics. Palgrave, Houndmills, Basingstoke, Hampshire RG 216XS and 175 Fifth Avenue, New York, N.Y. 10010.

NPC (2006). Population Census Figure of the Federal Republic of Nigeria, Abuja.

Oluyemi, J A; Roberts, F A (2000). Poultry Production in Warm-Wet Climate ( $2^{\text {nd }}$ Ed.) Spectrum Books Ltd. Ibadan, Nigeia.

Omotosho, O A (1997). Towards Increasing Resource Production in Nigerian's Industry. Proceeding of the First National Conference on Productivity Ibadan Nigeria, Macmillan Publisher.

Yusuf, S A; Malomo, O (2007). Technical Efficiency of Poultry Egg Production in Ogun State. A Data Envelopment Analysis (DEA) Approach. Int. J. Poult. Sci., 6(9): 622-629. 